\title{
The Impact of Gender Stereotyping on Female Expatriates; A Conceptual Model of Research
}

\author{
Vivek Mohan ${ }^{1 *}$, Naznin Tabassum ${ }^{2}$ \\ ${ }^{1}$ Senior Faculty in Management and Corporate Trainer, Exeed School of Business and Finance, \\ Westford Education Group, United Arab Emirates \\ ${ }^{2}$ Doctoral Researcher and Guest Lecturer, School of Human Resources and Organizational \\ Behaviour, Faculty of Business and Law, Leeds Beckett University, Leeds, UK
}

Received: October 12, 2017; Accepted: October 31, 2017; Published: November 21, 2017

*Corresponding author: Vivek Mohan, Senior Faculty in Management and Corporate Trainer, Exeed School of Business and Finance, Westford Education Group, United Arab Emirates. Email: - vivek@esbfedu.com ; v.mohan@shu.ac.uk

\begin{abstract}
Over the past decade, there has been an increasing amount of research on issues in expatriate performance management such as strategy and selection as a result of increasing assignments in international employees due to globalisation. Much of the literature dwells into male expatriates and the spouses of such expatriates, and not female expatriates sent for assignments abroad. While there are few comprehensive literature reviews about women expatriates in general, this paper attempts to gain a deeper understanding of the issue of gender stereotyping on female expatriates. This paper proposes a conceptual model to address new avenues for empirical and theoretical research on bridging the aspects of gender stereotyping and female expatriates.
\end{abstract}

Keywords: - Female Expatriates, Gender Stereotyping, Expatriate Assignments

\section{Introduction}

Over the past decade, a rising trend in female expatriates has caused organisations to re-think their perceptions with regard to women in international assignments $[10,30]$.Although female expatriates are bound to confront the phenomenon of "glass ceiling" initially to be able to pursue managerial positions abroad, Adler argued that low percentage of female expatriates is a result of lack of organisational confidence on the women's abilities and due to discrimination against women in foreign culture [1]. Research on female expatriates has been dominated by issues in the genre of cross-cultural adjustment and adaption the issue of gender stereotyping being highly under researched [5,18,21].In this context, evidence from Agars confirms the under examination of gender stereotypes that contribute to discrepancies in gender distribution [2]. Hence the purpose of this study is to develop a preliminary model of research to analyse the crucial factors and underlying implications of gender stereotyping on female expatriates. The findings from the review on existing studies indicate that large scale of research samples is essential to attain more focus on the relationship between organisational and individual perspectives involved in gender stereotyping on female expatriates.

The paper begins by explaining the research design and methodology adopted for the study. In the following section, the primary question for research is addressed: How can future research attain more clarity and focus on the issue of gender stereotyping of female expatriates? This question is answered by critically reviewing the existing literature on Gender stereotyping, the aspect of glass ceiling and female expatriates. Such a review leads us to the key themes, theorisations and factors reviewed in the management literature. Based on a review of existing literature in the area, the paper proposes a conceptual model which binds organisational factors from these two key findings to put forward new avenues for empirical and theoretical research on bridging the aspects of gender stereotyping and female expatriates.

\section{Research design and Methodology}

In order to provide an accurate and focussed review of management literature, this paper reviews publications with implications of terminologies 'Expatriate management', 'Female expatriates' and 'Gender stereotyping'. The searches were conducted using the databases Web of Science database, Psych INFO and ABI/INFORM to include all journals peer reviewed and published in the field of management. Moreover in an effort to apply more focus, these searches were also cross referenced using the EMERALD database of journals. The initial search with keywords 'Expatriate management and 'Female expatriates' returned 878 results over the past 25 years. The search was further streamlined with an additional terminology of 'Gender stereotyping' and a total of 188 articles contributed to the analysis and review. Such a focus was necessary to analyse the 
perceptions of expatriate gender on the job performance of male and female expatriates. The final list of articles also confirmed that the gender stereotyping of female expatriates has been a highly under-researched area in management literature.

\section{Gender Stereotyping and Female expatriates in extant literature}

On reviewing the existing literature on the Female expatriates, it is clear that although a variety of research questions are put forward due to the unique job situation of the expatriates, the topic itself remains severely under-researched. Hence it is highly imperative to demonstrate the need for more conceptual clarity on this matter by dwelling into existing literature on expatriates and gender in detail. In this regard, a primary question will help us justify our purpose:-

- How can future research attain clarity and focus on the issue of Gender stereotyping of female expatriates?

Black proposed that global organizations need to wider their selection process in terms of selecting best male and female candidates [6]. Adler had highlighted one of the reasons being discrimination against women in foreign culture [1]. Several studies yielded inconsistent results researching on gender and cultural stereotyping of women expatriates in foreign country cultures.

\section{Gender stereotyping in the international context}

Existing research suggest that various suggestions, practices and views that reinforce patriarchal systems and male operating systems are embedded in all cultures [23]. Adler found that expatriates were viewed as foreigners first than on the basis of their gender [1]. On Contrary, Harrison and Michailova suggested that western women expatriates in the UAE were perceived on the basis of gender first then as professionals [16]. Similarly, though the participants in the study conducted by Hutchings et al, suggested that expatriates were generally well regarded for their education, work experience and professionalism, they were required to work within the confines of what is acceptable behaviour for Emirati women in the cultural context of UAE [25]. The findings suggested that the female expatriates studied did not perceive gender and cultural stereotyping at work, but identified stereotyping as occurring in the non-work context, some of which resulted from the women engaging in auto-stereotyping. In this regard, Tzeng examined how female expatriates face gender stereotyping and discrimination in their home and host countries and how they reconcile their conflicts between homes and work [40]. Data were collected by conducting interviews with 21 female expatriates in Western multinational corporations with offices in Taiwan. The findings of the study suggested that gender discrimination might still exist towards female expatriates especially from males of the same ethnic background, for example, white female expatriates tend to be well received by Taiwanese because they are perceived as foreigners whereas ethnic Chinese female expatriates tend to be judged according to local standards for women despite of the fact that they might be different culturally. However, further research on ethnic differences in sex discrimination among female expatriates was warranted as the study is limited in its explanation of the ethnic perspective.

Two key concepts from the review confirm the need for organisational researchers to explore more theoretical and empirical venues in this area of research. Firstly, evidence on the role of organisational factors such as Organisational justice and Organisational support in shaping up perceptions about female expatriates and secondly, evidence from Schein's think managerthink male paradigm on the similarity of leader stereotypes to male and female stereotypes $[4,12,14,31,41]$.

\section{Key organisational factors shaping perceptions on female expatriates}

Several key organisational factors have been identified and presented in the table1 as critical factors which help shape perceptions of female expatriates [Table 1].

\begin{tabular}{|c|c|}
\hline $\begin{array}{l}\text { Organisational } \\
\text { factors }\end{array}$ & Extant literature \\
\hline \multirow{2}{*}{$\begin{array}{l}\text { Organisational } \\
\text { context }\end{array}$} & Schein, 1973;1975;1994 ;Lee,2005; Jokinen, \\
\hline & Brewster and Suutari,2008 \\
\hline \multirow{2}{*}{$\begin{array}{l}\text { Organisational } \\
\text { commitment }\end{array}$} & Schein, 1973;1975;1994;Chen and \\
\hline & Chiu,2009; Chen,2010; Thorn,2009 \\
\hline \multirow{4}{*}{$\begin{array}{l}\text { Organisational } \\
\text { justice }\end{array}$} & Pate and Scullion,2009; Haslberger and \\
\hline & Brewster,2009; \\
\hline & Forstenlechner,2010;Biemann and \\
\hline & Andresen,2010 \\
\hline Travel opportunities & Doherty, Dickmann and Mills,2011 \\
\hline \multirow{2}{*}{$\begin{array}{l}\text { Organisational } \\
\text { support }\end{array}$} & Schein, 1973;1975;1994 Yijala, \\
\hline & JasinskajaLahti, Likki and Stein,2012 \\
\hline $\begin{array}{l}\text { Organisational } \\
\text { capital }\end{array}$ & Al Ariss and Crowley Henry,2013 \\
\hline $\begin{array}{l}\text { Organisational } \\
\text { mobility }\end{array}$ & Doherty,2013; McNulty,2014 \\
\hline $\begin{array}{l}\text { Organisational } \\
\text { culture }\end{array}$ & $\begin{array}{c}\text { Schein, 1973;1975;1994; Chen and } \\
\text { Chiu,2009 }\end{array}$ \\
\hline
\end{tabular}

\section{The phenomenon of 'glass ceiling'}

Regarding understanding Glass ceiling, the aspect of Gender stereotyping is basic as it gives a knowledge into the desires individuals have about the sort of individual being reasonable for a given position in an organisation. The presence of the 'glass ceiling' isn't constrained to the United States. Truth be told, scientists have contemplated this phenomenon in many parts of the world, for example, Germany, Austria, UK, Bangladesh, Taiwan, and so forth to build the mindfulness and to help expel the confusion of the conventional generalization that females 
don't make great best level supervisors [28]. Glass ceiling "GC" is considered as one of the persuading analogies used to look at imbalances amongst men and ladies in the working environment $[7,17]$. "The discriminatory constraint alludes to an undetectable yet impermeable obstruction that confines the professional success of ladies. From that point forward, terms, for example, "sticky floors" and "concrete walls" have been utilized to allude to comparable and related snags - the challenges skilled ladies encounter in propelling their professions in medium and expansive associations" [7].

\section{The global phenomenon of think manager- think male paradigm}

Schien et al, suggests that leadership positions have been historically and traditionally believed to be as man's domain. "Think manager Think male" is considered a global phenomenon suggesting that leadership positions traditionally and historically believed as man's domain [35]. A research study has been conducted by Mirza and Jabeen in the South Asian countries contributing to the limited literature of the impact of gender stereotyping, specifically in banking Sector of the Pakistan to find the influence of gender stereotypes on women bankers in management positions and the findings suggested that stereotypes have a negative impact on perception of women in management [27].

The relationship between sex role stereotypes and successful managerial characteristics was investigated in Japan and the People's Republic of China [35]. A sample comprised of 123 female and 150 male undergraduate upper class students studying in a school of business in China and 105 females and 211 males enrolled in business courses at a university in Japan were chosen for the purpose of the study. Schein's 92-item descriptive index questionnaires were administered on the participants and the data were analysed by computing intra class correlation coefficients ( $\left.r^{\prime}\right)$ from two randomised groups of variance to determine the degree of resemblance between the descriptions of men and managers and women and managers. The two analyses were performed separately. The findings revealed that men and women in both countries viewed the successful managerial characteristics to be more of men's attributes than women's. Comparing this result to the findings of the previous study conducted in the US, United Kingdom and Germany, it was noticed that there was a significant degree of sex stereotyping among male management students and the managerial sex stereotyping was also confirmed among the females management students in all the countries except US [33]. Thus, the authors suggested that the Think Manager, Think Male is a global phenomenon.

\section{Discussion and future research implications}

The studies have proved that there are differences between organizations how they delegate their information sources and support among men and women. The failure of organizations to provide these elements for women decreases their possibility of success during the international assignment. Organizational support can be cross-cultural training of host country values and norms relating to women and possible problematic situations female expatriates may encounter during the assignment. This factor may be critical when predicting the success of female expatriates [8].The research of Linehan and Scullion indicate that the number of women in international management will remain a minority until organizations re-examine their IHRM practices [24]. Information about the specific requirements of women

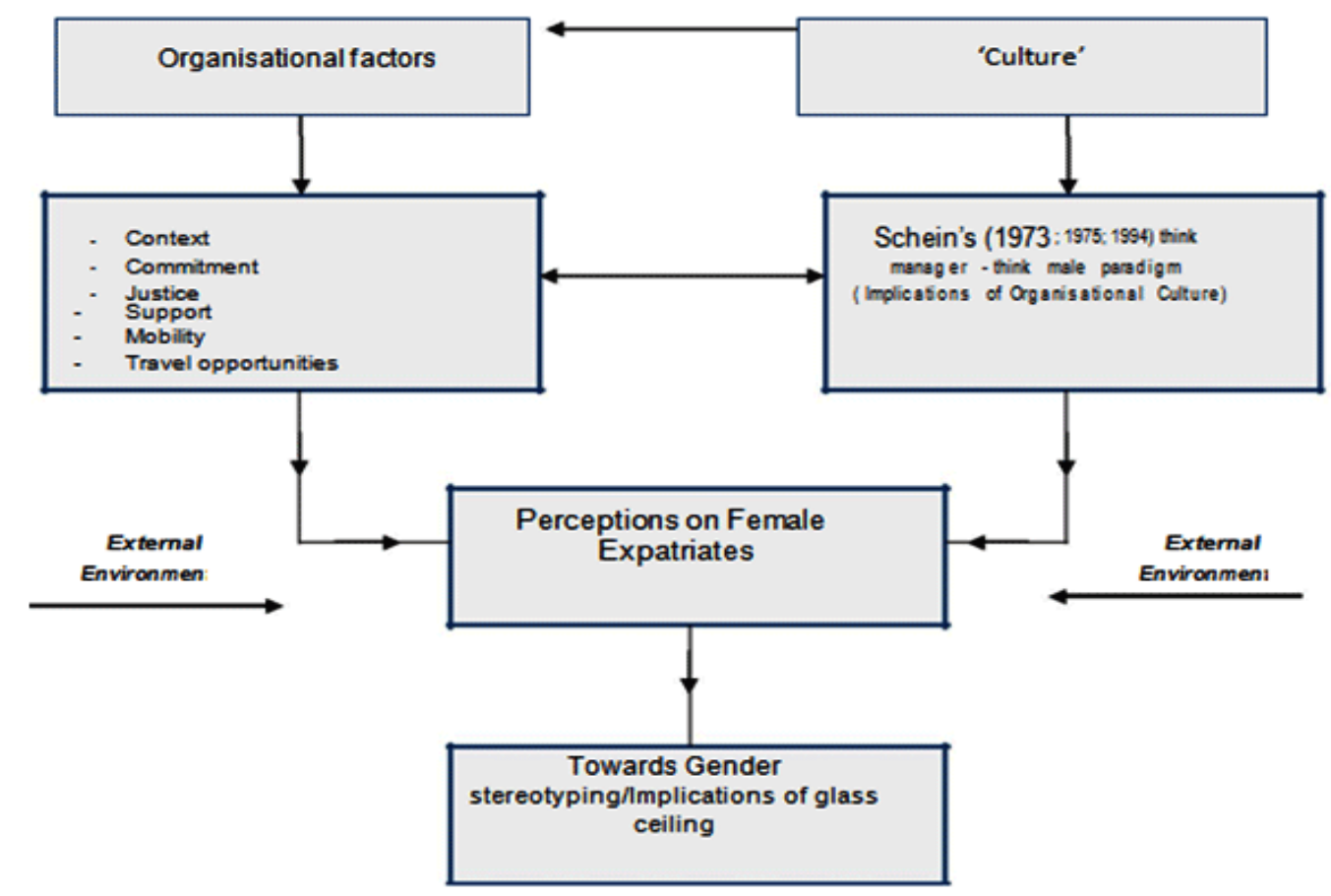

Figure 1: A conceptual framework for future research implications

Citation: Vivek Mohan, Tabassum N (2017) The Impact of Gender Stereotyping on Female Expatriates; A Conceptual Model of Research. Int J Fam Busi Manag 1(1): 1-5. 
who might be interested in a career abroad should be collected by organizations. Also organizations should understand what motivates women and drives their career aspirations. In the future the challenge for companies is to create a pool of female expatriates who could act as mentors and role models for females who wish to break through the glass ceiling and into careers abroad [24].

Figure1 represents a framework for future research implications [Figure 1]. The framework is based on previous research on the organisational factors which shapeup perceptions on female expatriates and Schein's think manager-think male paradigm on the similarity of leader stereotypes to male and female stereotypes [11,19,22,31,41].

As Figure 1 represents, this paper confirms that from reviewing the existing studies, organisational factors and the impact of 'culture' in terms of Schein's studies clearly play a crucial role in the formulation of perceptions of stereotyping of female expatriates in international assignments [31,32,34]. With this research paper, along with analysing the under researched area of gender stereotyping of female expatriates and the current perspectives in literature, we address the crucial shortcomings and propose a research framework for future avenues in the area. One can argue that host countries equipped with more traditional ideologies will be in fact more challenging for female expatriates. Although there are significant reasons to believe that our research model is applicable to pursue further research on bridging gender and expatriation due to the key mechanisms which are considered for analysis, more work to examine the potential differences in the impact of gender on female expatriate assignments is necessary. Finally, research has often addressed the performance of expatriate employees in general as being dependant on a large variety of factors $[12,39]$. From the perspective of gender stereotyping of female expatriates in the current literature, we have singled out the primary organisational drivers of stereotyping. Nevertheless, future research could pursue this matter and examine the impact of other relevant factors in the genre of Individual and Societal drivers. It is only rational to propose that the next step would be to test our research model. Hence the conceptual model addresses crucial shortcomings in this new area and contributes to the theory development of gender issues and the real impact of lives of employees and their experience within organisations. From a practical perspective, the study opens a window for HRD practitioners and global organisations with useful insights on providing equal opportunities to male and female candidates in overseas assignments.

\section{References}

1. Adler NJ. "An international perspective on the barriers to the advancement of women managers." Applied Psychology: An International Review. 1993;42(4):289 -300. doi: 10.1111/j.14640597.1993.tb00745.x

2. Agars MD. "Reconsidering the Impact of Gender stereotypes on the Advancement of Women in Organizations." Psychology of Women Quarterly. 2004;28(2):103-111. doi:10.1111/j.14716402.2004.00127.x
3. Alvesson M, Billing YD. Understanding gender and organisations. London: Sage. 1997

4. Biemann T, Andresen M. "Self-initiated foreign expatriates versus assigned expatriates: two distinct types of international careers?" Journal of Managerial Psychology. 2010;25(4):430-448. doi:10.1108/02683941011035313

5. Bhatti MA, Sundram VPK, Hee HC. "Expatriate Job Performance and Adjustment: Role of Individual and Organizational Factors". Journal of Business and Management. 2012;1(1):29-39.

6. Black JS. "Coming home: the relationship of expatriate expectations with repatriation adjustment and job performance". Human Relations. 1992;45(2). doi:10.1177/001872679204500205

7. Burke R, Vinnicombe S. Advancing Women's Careers. Career Development International. 2005;10(3):165-167. doi:10.1108/13620430510732012

8. Caligiuri PM, Joshi A, Lazarova M. Factors influencing the adjustment of women on global assignments. International Journal of Human Resource Management. 1999;10(2):163-179.

9. Chen HF, Chiu YH. "The influence of psychological contracts on the adjustment and organisational commitment among expatriates: An empirical study in Taiwan."International Journal of Manpower. 2009;30(8):797-814. doi:10.1108/01437720911004434

10. Cole N, McNulty Y. "Why do female expatriates "fit-in" better than males? An analysis of self-transcendence and socio-cultural adjustment." Cross cultural Management: An International Journal. 2011;18(2):144-164. doi:10.1108/13527601111125996_

11. Doherty N. "Understanding the Self-initiated Expatriate: A Review and Directions for Future Research". International Journal of Management Reviews. 2013;15(4):447-469. doi:10.1111/ijmr.12005

12. Doherty N, Dickmann M, Mills T. "Exploring the motives of company backed and self-initiated expatriates." International Journal of Human Resource Management. 2011;22(3):595-611. doi.10.1080/0 9585192.2011.543637

13. Eagly $\mathrm{AH}$, Karau SJ. Role congruity theory of prejudice toward female leaders. Psychological Review. 2002;109(3):573-598. doi:10.1037//0033-295X.109.3.573

14. Forstenlechner I. "Exploring expatriates' behavioural reaction to institutional injustice on host country level." Personnel Review. 2010;39(2):178-194. doi:10.1108/00483481011017408

15. Galanaki E, Papalexandris N, Halikias J. Revisiting leadership styles and attitudes towards women as managers in Greece: 15 years later. Gender in Management: An International Journal. 2009;24(7):484504 .doi:10.1108/17542410910991782

16. Harrison EC, Michailova S. Working in the Middle East: Western female expatriates' experiences in the United Arab Emirates. The International Journal of Human Resource Management. 2012;23(4):625-644. doi:10.1080/09585192.2011.610970

17. ILO. Breaking through the Glass Ceiling: Women in Management. Update 2004. Geneva: International Labour Organization. 2004

18. Jenkins EM, Mockaitis AI. "You're from where? The influence of distance factors on New Zealand expatriates' cross-cultural adjustment." The International Journal of Human Resource Management. 2010;21(15):2694-2715. 
19. Jokinen T, Brewster C, Suutari V. "Career capital during international work experiences: Contrasting self-initiated expatriate experiences and assigned expatriation", The International Journal of Human Resource Management. 2008;19(6):979-998. doi:10.1080/09585190802051279

20. Kang LS. Women on Corporate Boards: A Literature Review. Indian journal of Corporate Governance. 2012;5(1):32-49. doi:10.1177/0974686220120103

21. Lazarova M, Caligiuri P. "Retaining repatriates: The role of organizational support practices." Journal of world business. 2002;36(4): 389-401. doi:10.1016/S1090-9516(01)00063-3

22. Lee $\mathrm{CH}$. "A study of underemployment among self-initiated expatriates". Journal of World Business. 2005;40(2):172-187. doi:10.1016/j.jwb.2005.02.005

23. Linehan M. Senior female international managers: why so few? Ash gate Publishing. 2000

24. Linehan M, Scullion H, Walsh JS. Barriers to women's participation in international management. European Business Review. 2001;13(1):10-19. doi:10.1108/09555340110366444

25. McNulty Y, De Cieri H, Hutchings K. Expatriate return on investment in the Asia Pacific: An empirical study of individual ROI versus corporate ROI. Journal of World Business. 2013;48(2):209-221. doi:10.1016/j.jwb.2012.07.005

26. Mihail D. Gender-based stereotypes in the workplace: the case of Greece. Equal Opportunities International. 2006;25(5):373-388. doi:10.1108/02610150610706708

27. Mirza A, Baig M, Jabeen, N. Gender Stereotypes and Women in Management: The Case of Banking Sector of Pakistan. A Research Journal of South Asian Studies. 2011;26(2):259-284.

28. Pai K, Vaidya S. Glass Ceiling: Role of Women in the Corporate World. Competition Forum. 2009;19(2):106-113. doi. org/10.1108/10595420910942270

29. Powell GN. The Effects of Sex and Gender on Recruitment. Academy of Management Review. 1987;12(4):731-743.

30. Selmer J, Leung A. "International adjustment of female vs male business expatriates". International Journal of Human Resource Management. 2003;14 (7):1117-1131.

31. Schein VE. "The relationship between sex role stereotypes and requisite management characteristics." Journal of Applied Psychology. 1973;57(2):95-100.
32. Schein VE. Relationships between sex role stereotypes and requisite management characteristics among female managers. Journal of applied psychology. 1975;60(3):340.

33. Schein VE, Muller R. Sex role stereotyping and requisite management characteristics: a cross cultural look. Journal of Organisational Behaviour. 1992;13(5):439-447. doi:10.1002/job.4030130502

34. Schein VE. Managerial sex typing: A persistent and pervasive barrier to women's opportunities. Women in management: Current research issues. 1994;41-52.

35. Schein VE, Mueller R, Lituchy T, Liu J. Think manager-think male: a global phenomenon? Journal of Organisational Behaviour. 1996; 17(1):33-41. doi:10.1002/(SICI)1099-1379

36. Schwab K, Eide EB, Zahidi S, Bekhouche Y, Ugarte PP, Camus J, et al. The Global Gender Gap Report. World Economic Forum [Internet]. 2014;1-395.

37. Skelly J, Johnson JB. Glass Ceilings and Great Expectations: Gender Stereotype Impact on Female Professionals. Southern Law Journal. 2011;21:59-70.

38. Süssmuth-Dyckerhoff C, Wang J, Chen J. Women Matter: An Asian Perspective. McKinsey Report. Australia: New Media. 2012

39. Takeuchi R, Wang M, Marinova SV. "Antecedents and consequences of psychological workplace strain during expatriation: a cross sectional and longitudinal investigation." Personnel Psychology. 2005;58(4):925-948.

40. Tzeng R. Gender issues and family concerns for women with international careers: Female expatriates in Western multinational corporations in Taiwan. Women in Management Review. 2006;21(5):376-392. doi:10.1108/09649420610676190

41. Vance CM, McNulty Y. "Why and How Women and Men Acquire Global Career Experience: A Study of American Expatriates in Europe". International Studies of Management\& Organization. 2014;44(2):34-54.

42. Weyer B. Twenty years later: explaining the persistence of the glass ceiling for women leaders. Women in Management Review. 2007;22(6):482-496. doi:10.1108/09649420710778718

43. Wirth L. Breaking through the Glass Ceiling: Women in Management. Geneva: International Labour Office. 2001

44. Zafarullah H. Through the Brick wall and the Glass Ceiling: Women in the Civil Service in Bangladesh. Gender. Work and Organization. 2000;7(3):197-209. doi:10.1111/1468-0432.00107 